\title{
KOBILLERDE DIŞ TİCARET SORUNLARI: ANTALYA İLİ ÖRNEĞİ
}

\author{
Doç. Dr. Özlem ÇETINKAYA BOZKURT* \\ Mehmet Akif Ersoy Üniversitesi, Bucak İşletme Fakültesi, (ozlemcetinkaya@mehmetakif.edu.tr) \\ Dr. Öğr. Üyesi Hakan TUNÇ \\ Mehmet Akif Ersoy Üniversitesi, İ̈BF, (htunc@mehmetakif.edu.tr)
}

\begin{abstract}
ÖZET
Türkiye gibi gelişmekte olan ülkelerde üretimin ve ihracatın büyük çoğunluğu KOBI'ler tarafindan gerçekleşmektedir. Dolayısıyla bu ülkelerde KOBI'leri ve KOBİ'lerin

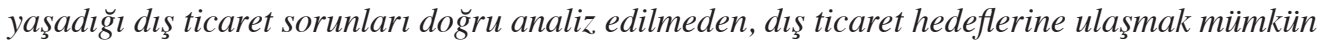
gözükmemektedir.

Buçalışmada Antalya ilinde faaliyet gösteren 119 firmaya uy gulanan bir anket yardımıyla, ilgili firmaların dış ticaret süreçlerinde yaşadıkları sorunlar tespit edilmeye çalışılmıştır. Bu sorunlar sırası ile döviz kurundaki hareketlilik, ülke ekonomisindeki istikrarsızlık, devlet desteğinin yetersiz olması şeklinde tespit edilmiştir. Ayrıca çalışmada firmaların yaşadı ̆̆ en önemli sorun olan döviz kuru hareketliliğin ihracatı olumsuz etkilediği dïşüncesi ile personel sayısı, işletmenin faaliyet alanı ve pazarlama faaliyet yürütücüsünün kim olduğu arasında istatistiksel olarak anlamlı farklılıklar saptanmıştır.
\end{abstract}

Anahtar Kelimeler: KOBİ, Dış Ticaret, Antalya, Varyans Modeli, Döviz Kuru.

\section{FOREIGN TRADE PROBLEMS IN SMES: SAMPLE OF ANTALYA}

\begin{abstract}
In the developing countries like Turkey, the major part of production and export is realized by SMEs. So, reaching foreign trade targets is impossible before analyzing SMEs and their problems in developing countries.

In this study, related organizations' problems on foreign trade process tried to capture with help of questionnaire applied on 119 organizations in Antalya. These problems were determined respectively volatility on currency rate, instability on economics and insufficient government assistance. Also statistically meaningful differences were found between the most important problem that companies face is the idea that volatility on currency rate affects exports negatively and personnel number, and between business segment and who operates marketing activities.
\end{abstract}

Keywords: SMEs, Foreign Trade, Antalya, Model of Variance, Currency Rate.

* Sorumlu Yazar

www.ijmeb.org ISSN:2147-9208 E-ISSN:2147-9194

http://dx.doi.org/10.17130/ijmeb.2018239938

Başvuru Tarihi: 19.08.2017, Yayına Kabul Tarihi: 09.01.2018 


\section{Giriş}

İhracatın kuruluşlar ve ekonomiler açısından oldukça önemli olduğu tartışılmaz bir gerçektir. Ekonomiye dış kaynak sağlayan ihracat, ülke ekonomisinin kalkınmasında ve gelişmesinde büyük roller üstlenmektedir. İhracatın artması milli geliri çoğaltır ve ülkedeki döviz darboğazının da ortadan kaldırılmasına katkıda bulunmak suretiyle ekonomik kalkınmaya destek olur (Sönmez \& Arslan, 2007). KOBİ'ler ihracata yöneldikten sonra elde edilecek döviz girdileri ile ülke ekonomisine katkıda bulunacaklar ve istihdam yaratacaklardır (Erdoğan \& Develioğlu, 2009:237).

KOBİ'leri ihracata yönelten çeşitli faktörler vardır. Bunlardan en önemlileri (Işık \& Delice, 2007; Ergen, 2011; Bagchi-Sen, 1999);

- Satış ve kârını artırmak,

- Büyümek

- Pazar darlığ 1 ,

- Pazardaki yüksek rekabet,

- İç pazara olan bağımlılı̆̆ı azaltmak,

- İç pazarda talebin az olması (enflasyon, dönemsel dalgalanma vb.)

- Dünya piyasalarından pay almak,

- Atıl kapasiteye sahip olma,

- Dış pazarlarda güçlü rakiplerin mamulleriyle rekabeti öğrenerek, iç pazarlarda da güçlü hale gelmek,

· Ülke dışındaki potansiyel pazar fırsatlarını değerlendirmek

- Ü̈lke dışından üretilen ürünlere yönelik talep oluşması

- Dış pazarlardaki vergi ve diğer teşvik avantajlarından yararlanmak şeklinde sıralamak mümkündür.

Küçük ve orta ölçekli işletmelerin ekonomik ve sosyal açıdan taşıdıkları önem, ülkeleri ve araştırmacıları bu işletmelerin sorunlarını gidermeye ve bu işletmelerden daha yüksek verim elde etmek yoluyla ülke ekonomisini güçlendirmeye yöneltmiştir. Dolayısıyla ülkemizdeki işletmelerin yaklaşık \%99,9'unu oluşturan, istihdamın \%76'sını, yatırımların ise \%50'sini sağlayan (TÜİK, 2016) KOBİ'lerin sorunlarına çözüm bulmaya çalışmak ekonomik ve sosyal açıdan önem arz etmektedir. Bu çalışmanın amacı; Antalya Organize Sanayi Bölgesi'nde faaliyet gösteren KOBİ'lerin, ihracat kapsamında yaşadıkları sorunları ortaya koymaktır. Bu sorunları belirleyebilmek adına anket tekniğinin kullanıldı ̆̆ı bir saha araştırması yapılmıştır. Bu çalışma ülkemizde Antalya'da faaliyet gösteren KOBI'lerin ihracat sorunlarını açıklayan benzeri çalışmaların çok fazla yapılmamış olması bakımından önemlidir.

\section{Kuramsal Çerçeve}

\subsection{KOBİ Kavramı ve KOBI'lerde Dış Ticaret}

Küçük ve Orta Büyüklükteki İşletmeler (KOBİ’ler), ekonomide istihdamın arttırılmasında, yenilikçilik ve ticarette önemli bir role sahiptir (Dicht vd., 1984; Dicht vd., 1990; Lyons, 
1995; Freeman, 1991; Rothwell, 1991). Türkiye'de ve dünyada çeşitli KOBİ tanımları yapılmaktadır. İşletme türlerinin, işletme faaliyet alanlarının, bölge ve ülke farklılıklarının olması ortak KOBİ tanımı yapmayı güçleştirmektedir. KOBİ tanımını etkileyen nitel ve nicel belli baş11 kriterler vardır. Bunlardan nitel kriterler; işletmenin faaliyet gösterdiği iş kolu içerisinde nispeten küçük bir paya sahip olması, işletme sermayesinin tümünün veya büyük bir bölümünün işletme sahibine ait olması, iş bölümü ve uzmanlaşma derecesi, girişimcinin işletmede fiilen çalışması, bağımsız yönetim (genelde işletmenin sahibi aynı zamanda yöneticisidir) ve modern yönetim tekniklerini uygulamada yetersizlik gibi sıralanabilir. Nicel kriterler ise, personel say1sı, sermaye, üretim miktarı, aktifler toplamı, makine paktı, pazar payı, kâr, kullandıkları enerji miktarı, satış hacmi gibi faktörlerden oluşmaktadır (Özgener, 2003:138).

Türkiye'de, 11.02.2017 tarihli Resmi Gazetede yayınlanan 12 seri nolu Kurumlar Vergisi Genel Tebliğinde Değişiklik Yapılmasına Dair Tebliğ ile 18/1/2017 tarihli ve 6770 sayılı Türkiye Cumhuriyeti Emekli Sandığı Kanunu ile Bazı Kanun ve Kanun Hükmünde Kararnamelerde Değişiklik Yapılmasına Dair Kanunla; KOBİ tanımı değişmiştir. Bu değişikliğe göre, KOBİ sayılan şirketin taşıması gereken iki şart bulunmaktadır. İlk şart personel sayısının 250 kişiden az olması iken ve ikinci şart; aktif büyüklüğü veya net satış hasılatının, gelir tablosunda yer alan yıllık net satış hasılatı veya bu dönemin sonunda çıkarılan bilançonun aktif toplamından herhangi birinin kırk milyon Türk Lirasını aşmamasıdır.

KOBİ tanımı, niteliği ve sınıflandırılması revize edilerek şu şekilde sınıflandırılmıştır (www.tobb.org.tr):

Tablo 1: Türkiye'de KOBİ Tanımı

\begin{tabular}{|c|c|c|c|}
\hline Kriter & $\begin{array}{c}\text { Mikro Ölçekli } \\
\text { KOBI் }\end{array}$ & $\begin{array}{c}\text { Küçük Ölçekli } \\
\text { KOBİ }\end{array}$ & $\begin{array}{c}\text { Orta Ölçekli } \\
\text { KOBİ }\end{array}$ \\
\hline Çalışan Personel Sayısı & $<10$ & $<50$ & $<250$ \\
\hline Yıllık Net Satış Hasılatı & $\leq 1$ Milyon TL & $\leq 8$ Milyon TL & $\leq 40$ Milyon TL \\
\hline Yıllık Mali Bilanço Toplamı & $\leq 1$ Milyon TL & $\leq 8$ Milyon TL & $\leq 40$ Milyon TL \\
\hline
\end{tabular}

Kaynak: https://www.tobb.org.tr/KobiArastirma/Sayfalar/KOBITanimi.php

2015 yılı TÜİK verilerine göre ihracatın \%55,1'i, ithalatın ise \%37,7'si KOBİler tarafından gerçekleştirilmiştir. İhracatta, 1-9 kişi çalışanı olan mikro ölçekli girişimlerin payı \%17,7 iken, 10-49 kişi çalışanı olan küçük ölçekli girişimlerin payı \%20,3, 50-249 kişi çalışanı olan orta ölçekli girişimlerin payı ise \%17,1 olmuştur (TÜİK, 2016). Yine aynı verilere göre; KOBİ'lerin ihracatının \%59,3'ü ticaret sektöründe,\%36'sı ise sanayi sektöründe faaliyet gösterenler tarafından yapıldığı anlaşılmaktadır. Ülke gruplarına göre 2015 'te dış ticaret verileri incelendiğinde, KOBI'ler tarafından yapılan ihracatın yüzde 49'u AB, yüzde 34,5'i Asya ülkelerine yapıldığı görülmektedir (TÜiK, 2016). Bu istatistiklere göre, Türkiye'deki KOBI'ler için Avrupa ülkeleri cazip bir pazar durumundadır.

\subsection{KOBİ'lerin İhracat Sorunları ve Kaynakları}

İhracat sorunları, şirketin uluslararası operasyonları başlatma, geliştirme veya sürdürme kabiliyetini engelleyen tutum, yapısal, operasyonel ve diğer kısıtlamalar olarak tanımlanabilir 
(Köksal \& Kettaneh, 2011:109). Çeşitli çalışmalar farklı perspektiflerden ihracat sorunlarına odaklanmış ve farklı metodolojileri kullanmıştır. Literatür, ihracat sorunlarının iç ve dış olarak sınıflandırılabileceğini önermektedir.

\subsection{1. Örgütsel Nedenlerden Kaynaklanan Sorunlar}

İçsel ihracat sorunları şirket içindeki sorunlara atıfta bulunur. Genellikle ihracat faaliyetleri için yetersiz olan işletme ve ürün özellikleriyle ilişkilidir (Köksal \& Kettaneh, 2011: 109). Dış ticaret faaliyetlerinde bulunan KOBİ'lerin, örgütsel yapıları, sahip oldukları finansal kaynaklar ve çalıştırdıkları personelin niteliği gibi değişkenlerin sebep olduğu sorunlardan bazıları şunlardır (Kaymak, 2015; Erdoğan \& Develioğlu, 2009; Altıntaş vd., 2007; Morgan \& Katsikeas, 1997; Leonidou, 1995; Katsikeas \& Morgan, 1994; Bilkey \& Tesar, 1977).

· Ürün kalitesi

- Üretim maliyetlerinin yüksekliği,

- Kalifiye eleman yetersizliği

- Ucuz ve kaliteli hammadde bulma güçlüğü

- Düşük kalitede ve düşük teknoloji ile üretim yapılması

- Ürünlerin ambalajlanmasında ve etiketlenmesinde yeterli olamamak

- Teknoloji ve Ar-Ge faaliyetlerinin yetersizliği

- Dış ticaret organizasyonlarının yeterince yardımcı olamaması

- İhracata yönelik üretim için kapasite yetersizliği

- Dış fiyatlandırmadaki yanlışlıklar

- Ürünlerin taşıma-depolama ve dağıtımında yaşanan güçlükler

- Siparişlerin zamanında teslim edilememesi

- Satış geliştirme ve tanıtım faaliyetlerindeki yetersizlikler

- Pazar araştırması yapamamak

- İhraç bedeli tahsilâtında yaşanan sıkıntılar

- Firmanın imajı

\subsection{2. Örgüt Dışından Kaynaklanan Sorunlar}

Dışsal ihracat sorunları, şirketin makro çevre koşullarından kaynaklanmakta ve ihracat piyasa yapısına ve ev sahibi hükümet politikalarına ilişkindir. İhracat pazarlarındaki rekabet, menşe ülke veya ülke imajı ve ev sahipliği yapan ülke hükümetleri tarafından uygulanan tarife / tarife dışı engeller gibi makro çevre güçleri, şirket ihracat performansını önemli ölçüde etkiler. Araştırmalar, saldırgan rakiplerin varlığını, rekabetçi fiyatların olmamasını ve ihracat pazarlarındaki rekabetin önemini vurgulamaktadır (Köksal \& Kettaneh, 2011:113). KOBİ'lerin örgüt dışındaki nedenlerden kaynaklanan ihracat sorunları arasında (Leonidou, 1995; Albaum, 1983; Morgan \& Katsikeas, 1997; Bilkey, 1978; Karafakioglu, 1986; Dicht vd., 1984; Leonidou, 1995; Ahmed vd., 2004); 
- Devlet desteklerinin ve teşvik tedbirlerinin yetersiz olması

- Ülke ekonomisindeki istikrarsızlık

- İhracatta yaşanan bürokrasi ve prosedürler

- Yabancı ülkelerin uyguladığı kotalar

- Rakipler ve rekabetin şiddeti

- Banka hizmetlerinin yetersiz olması

- Navlun sigorta bedellerinin yüksek olması

- Dövizdeki dalgalanmalar

- Ülke imaj1

- Kültür

- Farklı müşteri tutumları

- Dil ve iletişim farklılıkları

- Yüksek tarife ve tarife dışı engeller yer almaktadır.

\subsection{KOBİ'lerin Dış Ticaret Sorunlarına İlişkin Yapılmış Çalışmalar}

1960 ile 1970 yıllar arasındaki KOBİ'lerin ihracatındaki engellere ilişkin çalışmalarda beş önemli sorun tespit edilmiştir. Bunlar; evrak işleri, güvenilir bir distribütör seçimi, tarife dışı engeller, akredifler ve müşterilerle olan iletişim olarak sıralanmaktadır (Bilkey, 1978).

1980 yılların sonlarında konuyla ilgili pek çok çalışma yapılmıştır. Örneğin, Hook ve Czinkota (1988), ihracatçı olmayan KOBİ'lerin, ihracat faaliyetinin başlatılmasıyla ilgili sorunlara (ilk yatırımın artırılmasında yaşanan güçlükler, tarife ve tarife dışı engeller ve ihracat hakkında bilgi eksikliği gibi) büyük önem verdiklerini tespit ettiler. İhracatçı KOBİ'ler ise, esas olarak operasyonel konulara odaklanmışlardı (çok fazla kırtasiyecilik, ulaşım zorluğu, eğitimsiz personel gibi).

1990'lı yıllarda ise Finlandiya, Brezilya, Almanya, Yunanistan, Güney Kore ve Türkiye olmak üzere Anglo-Sakson olmayan ülkelerde konuyla ilgili çok sayıda araştırma yapılmıştır (Rocha vd., 2008). Araştırma sonuçlarına göre yurtdışı pazarlardaki şiddetli rekabet en önemli sorun olarak algılanmaktadır. KOBİ'ler için yurtdışında rekabet edebilecek fiyatlar belirleyememek, dış pazarları analiz etme imkânının sınırlı olması neredeyse eşit öneme sahip olduğu tespit edilmiştir (Leonidou, 1995).

2000'li yılların başında konuya ilgili bilimsel dergilerde daha az sayıda çalışmanın yer aldığı görülmektedir. Bu alandaki az sayıdaki çalışmanın yanı sıra Shaw ve Darroch (2004), ihracatçı olmayan ülkelerde uluslararasılaşmanın önündeki engeller konusunda bir takım önemli farklılıklar tespit etmişlerdi. Bunlar; sınırlı mali kaynaklar, sermayeye sınırlı erişim, hükümet desteğinin eksikliği, firma büyüklüğü, sınırlı pazar bilgisi, sınırlı tecrübeler, teşvikler, sınırlı piyasa bilgisi ve sınırlı mali kaynaklar gibi etkenler olarak sıralanabilir. Rocha ve arkadaşlarının (2008), ihracattaki algılanan engelleri ve doğasını anlamaya çalıştıkları araştırmaları çok sayıda araştırmacıya ilham kaynağı olmuştur (Leonidou 1995, 2004). Ayrıca, ihracat, uluslararası pazarlama teorisinin inşası için de umut verici bir alan olarak kabul edilmiştir (Zou \& Stan, 1998). 
Bagchi-Sen (1999) Kanada'daki KOBİ’lerin ihracatının önündeki engelleri içsel ve dışsal nedenler olarak iki grupta toplamıştır. İçsel nedenler arasında; firmanın büyüklüğü, finansal gereksinimler, işletme sermayesinin eksikliği, kurum içi uzmanlığın olmaması, riskteki isteklilik, etkisiz yönetim, yönetim zamanı gereksinimleri, fakir emek-yönetim ilişkisi, eskimiş fabrika ve ekipmanlar yer almaktadır. Dışsal nedenler ise; kültürel farklılıklar, lisanslama gereksinimleri, kuruluş hakkı, göçmenlik sorunları, devlet kontrolleri ve yönetmelikler, üretim girdilerinin artan maliyetleri, çalışan istihdamına yönelik sorunlar, üretim girdisi sıkıntısı, azalan ürün talebi, güçlü yerli rekabet, yabancı üreticilerle yaşanan güçlü rekabetten oluşmaktadır. Araştırma sonuçları, küçük kentsel yerleşim yerlerinden başarılı ihracatçıların hem ürün hem de süreç yeniliğine aktif bir şekilde dahil olduklarını doğrulamaktadır.

İhracat engellerini farklı sınıflandırmasını öneren çok sayıda çalışma bulunmaktadır (Çavuşgil \& Zou 1994; Morgan 1997; Tesfom \& Lutz 2006; Leonidou 2004). Örneğin Çavuşgil \& Zou (1994) bir ihracat girişimi pazarlama stratejisinin iç kuvvetler (şirket ve ürün özellikleri) ve dış kuvvetler (sanayi ve ihracat pazarı özellikleri) tarafından belirlendiğini ifade etmiştir. Benzer şekilde, Tesfom \& Lutz (2006), küçük ve orta ölçekli imalat firmalarının ihracat sorunlarını iç ve dış sorunlar olarak sentezlemişlerdir. Pinho \& Martins (2010) Portekiz'deki potansiyel ihracatçı ve ihracatçı olmayan KOBİ'lerin ihracat yapmasındaki bazı önemli engellerin belirlenmeyi amaçlamışlardır. Araştırmadan elde edilen sonuçlara göre, ihracatçı olmayan KOBI'lerin ihracat yapmasındaki engeller olarak; potansiyel piyasalar hakkında bilgi eksikliği, nitelikli ihracat personeli eksikliği, teknik uygunluk eksikliği, sektördeki rekabet derecesi ve mali yardım eksikliği (devlet ve finansal kurumlar) ile nitelikli insan kaynağının olmaması tespit edilmiştir. İhracatçı KOBİ'ler ise, hedef piyasadaki fiziksel ürün akışının depolanmasını ve kontrolünü en büyük engel olarak görüyorlardı. Khattak ve arkadaşları (2011) Pakistan'daki KOBİ'lerin mevcut ihracat zorluklarını ve bu engellerin KOBİ'leri nasıl etkilediğini incelemişlerdir. Bu çalışmanın bulgularına göre, iç engellerin (enerji krizi, politik-ekonomik-sosyokültürel çevre, pazarlama, fonksiyonel) diş engellerden (kalite ve fiyat rekabeti, ekonomik-politik-sosyokültürel çevre, ödeme, dil, belgeleme) daha etkili olduğunu ortaya koymuştur.

Türkiye'deki KOBİ'lerin ihracat işlemleriyle ilgili olarak günümüze kadar yapılan birçok araştırmadan da sorunların yıllar içinde çok fazla değişmediği görülmektedir (Tablo 2).

\section{Tablo 2: Türkiye'deki KOBI'lerin İhracat Sorunları Üzerine Yapılan Çalışmalar}

\begin{tabular}{|c|c|c|}
\hline Yazar & KOBI'lerin ihracatta Karşılaştıkları sorunları & $\begin{array}{l}\text { Çalışmanın Uygulama } \\
\text { yeri }\end{array}$ \\
\hline $\begin{array}{l}\text { Bodur } \\
\text { (1986) }\end{array}$ & $\begin{array}{l}\text { Yüksek üretim maliyetleri, evrak gecikmeleri, dış piyasa } \\
\text { bilgileri eksikliği, enerji sıkıntısı, taşımaya ilişkin sorunlar, } \\
\text { Yüksek ihracat kredisi maliyeti, Halka açık bir bilgi yayma } \\
\text { merkezinin eksikliği }\end{array}$ & $\begin{array}{l}88 \text { yiyecek ve tekstil } \\
\text { sektöründeki ihracatçı } \\
\text { KOBİ ve büyük firma }\end{array}$ \\
\hline $\begin{array}{l}\text { Karafakioğlu, } \\
\text { (1986) }\end{array}$ & $\begin{array}{l}\text { Yoğun uluslararası rekabet, yabancı pazarlar hakkında bilgi } \\
\text { eksikliği, yüksek risk, düşük kalitede üretim ve yüksek } \\
\text { maliyetler, İhracat kısıtlamaları ve formaliteleri, Teşvik } \\
\text { eksikliği }\end{array}$ & $\begin{array}{l}\text { İstanbul'da İhracat } \\
\text { yapan } 201 \text { adet } \\
\text { KOBI'ler }\end{array}$ \\
\hline
\end{tabular}




\section{Tablo 2 devam}

\begin{tabular}{ll}
\hline Karakaya \& & Finansal kaynakların eksikliği, hükümet tarafından sağlanan \\
Harcar & yetersiz piyasa bilgileri \\
$(1999)$ &
\end{tabular}

Farklı sektörde faaliyet

gösteren ve ihracat yapmayan 177 adet KOBİ

Kayseri ve Nevşehir'de

Finansman Sorunu, Uluslararası Tanıtım Faaliyetlerine

Delice İlişkin Sorunlar, Bürokratik Engeller, Rekabet Sorunu,

(2001) Üretim Maliyetleriyle İlgili Sorunlar, Yeterli Sayıda Nitelikli Personel Olmaması

faaliyette bulunan

ve KOSGEB'in veri

tabanında

İhracatçı olarak kayıtll

görünen 27 işletme

üzerinde

\begin{tabular}{|c|c|c|}
\hline & & \\
\hline $\begin{array}{l}\text { Karamustafa } \\
\text { vd. } \\
(2001)\end{array}$ & $\begin{array}{l}\text { Ürün maliyetlerinin rakip ülkelerdekine göre yüksek } \\
\text { olması, yabancı müşterilere ulaşamama, yabancı pazarları } \\
\text { tanımama, yatırım ve teknolojik yetersizlikler, kapasite } \\
\text { darlığı, ihracat konusunda bilgi yetersizliği, kalite } \\
\text { düşüklüğü }\end{array}$ & $\begin{array}{l}\text { Samsun ilindeki } \\
\text { KOBÍler }\end{array}$ \\
\hline $\begin{array}{l}\text { Çoban } \\
(2005)\end{array}$ & $\begin{array}{l}\text { Sektörün en önemli problemi tedarik kaynă̆ı ile işbirliğinde } \\
\text { yaşanan problemler, rekabetçi fiyat uygulamalarının } \\
\text { yaşattığı zorluklar, yabancı ülkelerdeki tüketicilerin farklı } \\
\text { alışkanlıkları, dış pazarla ilgili bilgi yetersizlikleri, yüksek } \\
\text { vergi oranları ve farklı kalite standartlarıdır. }\end{array}$ & $\begin{array}{l}\text { Kayseri mobilya } \\
\text { sanayinde yer alan } 30 \\
\text { işletme }\end{array}$ \\
\hline $\begin{array}{l}\text { Balantekin } \\
(2006)\end{array}$ & $\begin{array}{l}\text { İşletmelerin başlıca ihracat sorunlarının üretim maliyetleri, } \\
\text { ülke ve işletme imajı, finansal sorunlar, yetişmiş eleman ve } \\
\text { rekabet olduğu belirlenmiştir }\end{array}$ & $\begin{array}{l}\text { Kayseri Organize } \\
\text { Sanayi Bölgesinde } \\
\text { bulunan KOBI'ler }\end{array}$ \\
\hline $\begin{array}{l}\text { Demirel \& } \\
\text { Sezgin } \\
(2006)\end{array}$ & $\begin{array}{l}\text { İşletmelerin pazara açılım kararlarında en çok girişimcilerin/ } \\
\text { üst düzey yöneticilerin yaklaşımlarının etkili olduğu, } \\
\text { onların kararlarında da en çok dağıtım kanalı özellikleri } \\
\text { (öncelikle uluslar arası kanallarla çalışma koşullarının ve } \\
\text { coğrafik konum olarak uzak olan kanalların maliyetleri) } \\
\text { nin ve fiziksel dağıtım şartları (taşıma ve stoklamanın } \\
\text { maliyetleri ve zorlukları) nın etkili olduğu ortaya çıkmıştır. } \\
\text { Özellikle araştırma yapmadıkları/ yapamadıkları için yeterli } \\
\text { bilgiye sahip olmadıklarını, bilgileri bir şekilde elde edenler } \\
\text { ise bu çalışmaları yönlendirecek bilgi, birikim ve eğitime } \\
\text { sahip çalışanları olmadığını ifade etmektedirler. }\end{array}$ & $\begin{array}{l}\text { Dalıkesir İlinde farklı } \\
\text { sektörlerde faaliyet } \\
\text { gösteren } 100 \text { KOBİ }\end{array}$ \\
\hline $\begin{array}{l}\text { Işı1k \& Delice } \\
\text { (2007) }\end{array}$ & $\begin{array}{l}\text { İşletmelerin yoğun dış rekabeti ihracatları için engel } \\
\text { görmedikleri; Finansmanı için çalışma sermayesinin } \\
\text { yetersiz olmasını ihracat için engel, Yabancı pazarları } \\
\text { analiz etmede ve hedef pazarları belirlemede bilgi eksikliği, } \\
\text { yurtdışındaki yasal düzenlemeleri ihracat için ciddi bir } \\
\text { engel olarak görmektedir. Karaman'daki işletmelerin \%60 } \\
\text { gibi yüksek bir oranı elverişsiz kur oranlarını ihracat için } \\
\text { engel olarak görürken, sözkonusu oran Nevşehir için sadece } \\
\text { \%20'dir. }\end{array}$ & $\begin{array}{l}\text { Karaman ve Nevşehir } \\
\text { illerinde faaliyet } \\
\text { gösteren KOBİ } \\
\text { niteliğindeki } 35 \\
\text { ihracatçı firma }\end{array}$ \\
\hline
\end{tabular}


Tablo 2 devam

\begin{tabular}{|c|c|c|}
\hline $\begin{array}{l}\text { Sönmez \& } \\
\text { Arslan } \\
\text { (2007) }\end{array}$ & $\begin{array}{l}\text { Elverişsiz kur oranlarının, yabancı pazarlarda yoğun } \\
\text { rekabetin etkili olması, devlet desteği ve teşviklerin yetersiz } \\
\text { oluşu, yurt dışındaki yasal düzenlemelerin tam olarak } \\
\text { bilinmemesinin etkisi, yüksek gümrük vergileri ve vergi } \\
\text { dışı engellerin etkili olduğu, nitelikli ihracat elemanlarının } \\
\text { eksikliği, ihracat finansmanı için çalışma sermayesinin } \\
\text { yetersizliği, ihracata yönelik bürokratik işlemlerin çokluğu }\end{array}$ & $\begin{array}{l}\text { Ankara ve Bursa/İnegöl } \\
\text { bölgelerinde tesadüfi } \\
\text { olarak seçilen } 97 \text { adet } \\
\text { işletme }\end{array}$ \\
\hline $\begin{array}{l}\text { Altıntaş vd. } \\
(2007)\end{array}$ & $\begin{array}{l}\text { Döviz kuru riski, Müşterilere tatmin edici fiyat sunmak, } \\
\text { Yurtdışı pazarlarda keskin rekabet, devlet yardımı / } \\
\text { teşviklerin olmaması, İhracatını finanse etmek için işletme } \\
\text { sermayesi yetersizliği, Piyasayı bulmak / analiz etmek } \\
\text { için sınırlı bilgi, Yüksek tarife ve tarife dışı engeller, } \\
\text { Türkiye'de bürokratik gerekler, Aşırı nakliye masrafları, } \\
\text { İhracat için yetersiz / eğitimsiz personel, İhracat dağıtım } \\
\text { kanallarına erişme, Olumsuz kurallar ve düzenlemeler, } \\
\text { Teknik / satış sonrası servis sağlama, Bilmediğiniz yabancı } \\
\text { iş uygulamaları, Yurtdışından gelen ödemelerin yavaş } \\
\text { tahsilatı, İhracat için üretim kapasitesinin olmaması, İhracat } \\
\text { ürün kalite standartlarını karşılamak, Yabancı iş fırsatlarını } \\
\text { tanımlayamamak, Farklı yabancı müşteri alışkanlıkları / } \\
\text { tutumları, dil ve iletişim farkı }\end{array}$ & $\begin{array}{l}145 \text { farklı sektördeki } \\
\text { ihracat yapan KOBİ }\end{array}$ \\
\hline $\begin{array}{l}\text { Keskin vd. } \\
\text { (2009) }\end{array}$ & $\begin{array}{l}\text { Mevzuata ilişkin sorunlar ve bürokratik engeller, ekonomik } \\
\text { istikrarsızlık, dış talep yetersizliği, finansman yetersizliği, } \\
\text { dış pazarlar hakkında bilgi eksikliği ve nitelikli personel } \\
\text { eksikliği }\end{array}$ & $\begin{array}{l}\text { Erzurum Organize } \\
\text { Sanayi Bölgesinde } \\
\text { faaliyette bulunan } \\
\text { Kobi'ler }\end{array}$ \\
\hline $\begin{array}{l}\text { Ergen } \\
(2011)\end{array}$ & $\begin{array}{l}\text { Rekabetten kaynaklanan sorunlar, Fiyatların yüksekliğinden } \\
\text { kaynaklanan sorunlar, ihracatın finansmanıyla ilgili sorunlar, } \\
\text { Üründe kalite, ambalaj ve standardizasyon sorunları, Satış } \\
\text { arttırma teknikleri (reklâm gibi) kullanamama, Nakliye, } \\
\text { depolama sorunları, ihracat mevzuatındaki istikrarsızlık } \\
\text { Yurt dışı satış dağıtım organizasyonu eksikliği }\end{array}$ & $\begin{array}{l}\text { Konserve Meyve-Sebze } \\
\text { Sektöründe yer alan } \\
\text { KOBI'ler }\end{array}$ \\
\hline $\begin{array}{l}\text { Köksal \& } \\
\text { Kettaneh } \\
(2011)\end{array}$ & $\begin{array}{l}\text { Yetersiz üretim kapasitesi, yabancı pazar bilgilerini elde } \\
\text { etmede güçlükler, piyasa potansiyelinin belirlenmesi, } \\
\text { ihracatta nitelikli personel eksikliği, kalitesiz ürünler, } \\
\text { yetersiz ürün karışımı, ambalajlama ve zayıf marka imajı. } \\
\text { İhracatta karşılaşılan sorunların çoğu her iki örnekteki } \\
\text { şirketler için aynıdır. }\end{array}$ & $\begin{array}{l}144 \text { adet Türkiye'de } \\
\text { farklı sektörlerde } \\
\text { faaliyet gösteren KOBİ } \\
\text { ve } 71 \text { adet Lübnan'daki } \\
\text { KOBİ }\end{array}$ \\
\hline $\begin{array}{l}\text { Şahin } \\
(2016)\end{array}$ & $\begin{array}{l}\text { Ürünlerin kalite ve standardizasyon eksikliği, Rakiplerin } \\
\text { ve rekabet edebilme şiddetinin yoğun olması, Hedef pazar } \\
\text { araştırması ve ürün tanıtım eksikliği, Verimliliğin düşük ve } \\
\text { Maliyetlerin yüksek olması, Benzer işletmelerle işbirliği } \\
\text { yapılamaması, Finansman sorunları, Donanımlı dış ticaret } \\
\text { elemanı eksikliği, Fuar, teşvik gibi olanaklardan haberdar } \\
\text { olmama, AR-GE ve inovasyon eksikliği. }\end{array}$ & $\begin{array}{l}\text { Kuyumcukent'te } \\
\text { kuyumculuk sektöründe } \\
\text { faaliyet gösteren } 45 \\
\text { ihracatçı firma }\end{array}$ \\
\hline
\end{tabular}




\subsection{Antalya İli Dış Ticaret Yapısı}

Antalya ili Türkiye'nin önemli turizm ve diş ticaret merkezlerinden biridir. Antalya ilinde 2016 yılında gerçekleşen ihracat miktarı 976 milyon dolardır. Antalya ilinde en çok ihracat yapan sektörler meyve-sebze sektörü ve madencilik sektörüdür (Baka, 2014:27). 2016 yılında Türkiye'de toplam 142 milyar dolar ihracat gerçekleşmiştir (TUİK, 2017). Antalya ili tek başına Türkiye ihracatının binde 7'sini gerçekleştirmektedir.

Tablo 3: Antalya'nın Dış Ticaret Yapısı

\begin{tabular}{lcccccc}
\hline Yıl & $\begin{array}{c}\text { İhracat } \\
\text { (Dolar) }\end{array}$ & $\begin{array}{c}\text { İthalat } \\
\text { (Dolar) }\end{array}$ & $\begin{array}{c}\text { Diş Ticaret } \\
\text { Açı̆ı }\end{array}$ & $\begin{array}{c}\text { Karşlama } \\
\text { Oranı }\end{array}$ & $\begin{array}{c}\text { İhracat } \\
\text { Büyüme }\end{array}$ & $\begin{array}{c}\text { İthalat } \\
\text { Büyüme }\end{array}$ \\
\hline $\mathbf{2 0 0 2}$ & 165.989 .350 & 109.804 .924 & 56.184 .426 & 151 & $0 \%$ & $0 \%$ \\
\hline $\mathbf{2 0 0 3}$ & 324.990 .267 & 161.475 .693 & 163.514 .574 & 201 & $96 \%$ & $47 \%$ \\
\hline $\mathbf{2 0 0 4}$ & 457.829 .376 & 397.838 .996 & 59.990 .380 & 115 & $41 \%$ & $146 \%$ \\
\hline $\mathbf{2 0 0 5}$ & 396.314 .624 & 382.843 .825 & 13.470 .799 & 104 & $-13 \%$ & $-4 \%$ \\
\hline $\mathbf{2 0 0 6}$ & 437.115 .292 & 412.235 .227 & 24.880 .065 & 106 & $10 \%$ & $8 \%$ \\
\hline $\mathbf{2 0 0 7}$ & 650.608 .966 & 462.535 .007 & 188.073 .959 & 141 & $49 \%$ & $12 \%$ \\
\hline $\mathbf{2 0 0 8}$ & 724.563 .219 & 616.693 .460 & 107.869 .759 & 117 & $11 \%$ & $33 \%$ \\
\hline $\mathbf{2 0 0 9}$ & 655.414 .065 & 460.570 .028 & 194.844 .037 & 142 & $-10 \%$ & $-25 \%$ \\
\hline $\mathbf{2 0 1 0}$ & 864.215 .958 & 816.585 .737 & 47.630 .221 & 106 & $32 \%$ & $77 \%$ \\
\hline $\mathbf{2 0 1 1}$ & 961.010 .841 & 689.246 .156 & 271.764 .685 & 139 & $11 \%$ & $-16 \%$ \\
\hline $\mathbf{2 0 1 2}$ & 977.894 .778 & 666.709 .059 & 311.185 .719 & 147 & $2 \%$ & $-3 \%$ \\
\hline $\mathbf{2 0 1 3}$ & 1.047 .252 .76 & 754.465 .866 & 292.786 .900 & 139 & $7 \%$ & $13 \%$ \\
\hline $\mathbf{2 0 1 4}$ & 1.032 .681 .57 & 808.191 .617 & 224.489 .890 & 128 & $-1 \%$ & $7 \%$ \\
\hline $\mathbf{2 0 1 5}$ & 961.270 .159 & 976.463 .065 & -15.192 .906 & 98 & $-7 \%$ & $21 \%$ \\
\hline $\mathbf{2 0 1 6}$ & 976.901 .566 & 1.112 .966 .49 & -136.064 .843 & 88 & $2 \%$ & $14 \%$ \\
\hline
\end{tabular}

Kaynak: Yazarlar tarafından TÜİK Verileri Kullanılarak Hazırlanmıştır.

Tablo 3'te Antalya ilinin 2002-2016 yılları arasında gerçekleşen ithalat -ihracat, ihracat ve ithalatta bir önceki yıla göre büyüme, Antalya iline ait dış ticaret açı̆̆ı verileri ile ihracatın ithalatı karşılama oranı verilmiştir. Antalya ilinin 14 yıllık verisi incelendiğinde son iki yıl dışında dış ticaret fazlası verdiği, 2015 ve 2016 yıllarında ise ithalat artışları nedeniyle dış ticaret açığı verdiği gözükmektedir. Antalya ilinde son 14 yılda ihracat 5,8 kat, ithalat ise 10 kat artmıştır. İhracatın ithalatı karşılama oranları incelendiğinde ise son iki yıl içinde verilerin olumlu olduğu gözükmektedir. 
Şekil 1: Antalya İli 2002-2016 Yılları Arası İhracat ve İthalat Trendi (Cari Rakamlar)

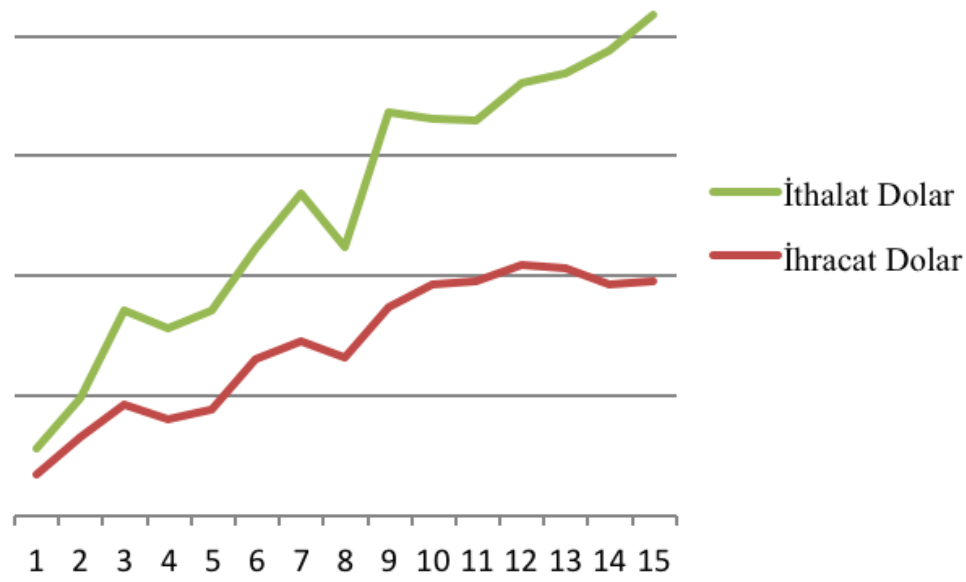

Kaynak: Yazarlar tarafından TÜİK Verileri Kullanılarak Hazırlanmıştır.

Şekil 1'de Antalya ilinin 2002- 2016 yılları arasında gerçekleşen ihracat ve ithalat verilerinin trend eğilimleri verilmiştir. Her iki grafiğinde artan eğilimde olduğu ithalat grafiğinin eğiminin ihracat grafiği eğimine daha yüksek olduğu net bir biçimde gözükmektedir. Her iki trendinde paralel hareket ediyor gibi gözükmesi korelasyon olasılığını güçlendirmiş olup Antalya ilinin ihracat ve ithalatı arasındaki ilişki sperman korelasyon analizi yardımıyla (Tablo 4) incelenmiştir.

Tablo 4: Sperman Korelasyon Tablosu (Büyüme)

\begin{tabular}{lccc}
\hline & $\begin{array}{c}\text { Korelasyon Katsayısı } \\
\text { (Sperman) }\end{array}$ & $\begin{array}{c}\text { Olasılık Değeri } \\
(\text { Sig })\end{array}$ & $\begin{array}{c}\text { Örneklem } \\
\text { Büyüklü̆ğ̈̈ }\end{array}$ \\
\hline $\begin{array}{l}\text { İhracat Büyüme- } \\
\text { Ithalat Büyüme }\end{array}$ &, 608 &, 016 & 15 \\
\hline
\end{tabular}

$\mathrm{P}<0,05$

Veri setindeki dönemin darlı̆̆ ${ }_{1}$ nedeniyle non-paremetrik bir korelasyon testi olan Sperman korelasyon testi kullanılmıştır (Büyüköztürk, 2007:31). Tablo 4 incelendiğinde ihracattaki büyüme ile ithalattaki büyüme arasında pozitif yönlü bir ilişki görülmektedir. Olasılık değeri her iki değişken için 0.05 'in altında çıkmıştır. Bu değer tablo altında da belirtildiği gibi $(\mathrm{p}<0,05) \% 95$ güven aralığında katsayıların istatistiksel olarak anlamlı olduğunu göstermektedir (Kalayc1, 2005:112). 


\section{Antalya İlinin Dış Ticaret Sorunları Üzerine Bir Uygulama}

Çalışmanın bu kısmında Antalya ilinde bulunan dış ticaret yapan 119 KOBİ’ye ihracat sürecinde yaşadıkları sorunları tespit etmek amacıyla bir anket uygulaması yapılmıştır. Soru formu ilgili firmaların dış ticaret bölümü sorumluları ve işletme sahipleri ile gerçekleştirilmiştir. Araştırmada kullanılan anket likert tipi ölçekte olup, 1 yanıtı "hiç katılmıyorum", 5 yanıtı ise, "tamamen katılıyorum" şeklinde kodlanmıştır. Güvenilirlik analizi sonucunda ölçeğin bir bütün olarak Cronbach's Alpha değeri 0,89 çıkmış olup, bu değer kullanılan ölçeğin oldukça güvenilir olduğunu göstermektedir (Kalaycı, 2005:405).

Tablo 5: Temel İstatistik Sonuçları $(M>3)$

\begin{tabular}{|c|c|c|c|c|c|}
\hline & $\mathbf{n N}$ & $\begin{array}{c}\text { Ortalama } \\
(\mathrm{M})\end{array}$ & $\begin{array}{c}\text { Std } \\
\text { Deviation } \\
\end{array}$ & Skewness & Kurtosis \\
\hline $\begin{array}{l}\text { Dövizdeki dalgalanmalardan } \\
\text { olumsuz yönde etkilenmekteyiz. }\end{array}$ & 118 & 3,4237 & 1,42269 & $-0,368$ & $-1,23$ \\
\hline $\begin{array}{l}\text { Ülke ekonomisindeki istikrarsılık } \\
\text { ihracatı olumsuz etkilemektedir. }\end{array}$ & 117 & 3,3248 & 1,35716 & $-0,232$ & $-1,197$ \\
\hline Devlet desteği yetersizdir. & 117 & 3,265 & 1,22751 & $-0,095$ & $-0,975$ \\
\hline $\begin{array}{l}\text { İhracat mevzuatında sürekli } \\
\text { yaşanan değişiklikler dış } \\
\text { ticaretimizi olumsuz etkilemektedir. }\end{array}$ & 118 & 3,2627 & 1,22947 & $-0,124$ & $-1,019$ \\
\hline $\begin{array}{l}\text { Ülkelerin uyguladığı kotalar } \\
\text { ihracatta olumsuzluklara yol } \\
\text { açmaktadır. }\end{array}$ & 116 & 3,181 & 1,18394 & $-0,071$ & $-0,792$ \\
\hline $\begin{array}{l}\text { Navlun sigorta bedellerinin yüksek } \\
\text { olması pazar payımızı etkiliyor. }\end{array}$ & 116 & 3,1034 & 1,30137 & $-0,002$ & $-1,113$ \\
\hline $\begin{array}{l}\text { Navlun bedelinin yüksek } \\
\text { olmasından dolayı istediğimiz } \\
\text { ülkelere ihracat yapamıyoruz }\end{array}$ & 116 & 3,0776 & 1,37778 & 0,021 & $-1,206$ \\
\hline $\begin{array}{l}\text { İhracatta bürokratik engeller } \\
\text { yaşamaktayız. }\end{array}$ & 117 & 3,0513 & 1,3445 & 0,057 & $-1,147$ \\
\hline $\begin{array}{l}\text { Uluslararası pazarlarda reklam } \\
\text { maliyetlerinin yüksek olmasından } \\
\text { dolayı zorluk çekiyoruz. }\end{array}$ & 117 & 3,0342 & 1,28608 & $-0,089$ & $-1,123$ \\
\hline $\begin{array}{l}\text { Ucuz ve kaliteli hammadde güçlüğü } \\
\text { çekmekteyiz. }\end{array}$ & 117 & 3,0171 & 1,47965 & 0,003 & $-1,463$ \\
\hline İhracat kredileri yetersizdir. & 117 & 3,0085 & 1,36139 & 0,047 & $-1,149$ \\
\hline
\end{tabular}

Tablo 5'de Antalya ilinde faaliyet gösteren KOBI'lerin dış ticaret sorunlarına ilişkin ifadelerin üçün üzerinde ortalamaya sahip olanları verilmiştir. 5'li likert kullanılan anketlerde ortalama değer üç olduğu için KOBİ'lerin cevaba ilişkin ortalama değerin üçün üstünde olması ilgili sorunun varlığına ilişkin genel bir eğilim olduğunu gösterir. Sonuç itibariyle Antalya ilinde ihracat yapan KOBİ'lerin en çok döviz kurundaki hareketlilik, ülke ekonomisindeki 
istikrarsızlık, devlet desteğinin yetersiz olması ve mevzuatta yaşanan sürekli değişikliklerden olumsuz etkilendiği gözükmektedir (Tablo 5).

Tablo 6: Temel İstatistik Sonuçları $(\mathrm{M}<3)$

\begin{tabular}{|c|c|c|c|c|c|}
\hline & $\mathbf{n N}$ & $\begin{array}{l}\text { Ortalama } \\
\text { (M) }\end{array}$ & $\begin{array}{c}\text { Std } \\
\text { Deviation }\end{array}$ & Skewness & Kurtosis \\
\hline $\begin{array}{l}\text { Yeni diş pazarlar bulma konusunda } \\
\text { zorluk çekiyoruz. }\end{array}$ & 114 & 2,9035 & 1,34342 & 0,09 & $-1,193$ \\
\hline $\begin{array}{l}\text { Dış pazarlamada nitelikli satış } \\
\text { elemanı istihdam etmekte güçlük } \\
\text { çekiyoruz. }\end{array}$ & 114 & 2,8947 & 1,45352 & 0,134 & $-1,343$ \\
\hline Banka hizmetleri yetersizdir. & 116 & 2,8707 & 1,30903 & 0,125 & $-1,009$ \\
\hline $\begin{array}{l}\text { Aracı maliyetlerimizi fiyata } \\
\text { yansıtmakta zorluk çekiyoruz. }\end{array}$ & 117 & 2,812 & 1,37673 & 0,144 & $-1,276$ \\
\hline $\begin{array}{l}\text { Satış geliştirme ve tanıtım } \\
\text { faaliyetlerini bütçe } \\
\text { yetersizliklerinden dolayı } \\
\text { gerçekleştiremiyoruz. }\end{array}$ & 115 & 2,713 & 1,375 & 0,265 & $-1,15$ \\
\hline $\begin{array}{l}\text { Dış pazarlar hakkında yeterli } \\
\text { bilgimizin olmaması Pazar payımızı } \\
\text { düşürmektedir. }\end{array}$ & 116 & 2,7069 & 1,37694 & 0,3 & $-1,116$ \\
\hline $\begin{array}{l}\text { Teslimatın zamanında yapılamaması } \\
\text { ihracatımızı olumsuz yönde } \\
\text { etkilemektedir. }\end{array}$ & 116 & 2,6724 & 1,31066 & 0,323 & $-0,965$ \\
\hline $\begin{array}{l}\text { İhracatta pazar araştırması yapmakta } \\
\text { zorluk çekiyoruz. }\end{array}$ & 118 & 2,661 & 1,32188 & 0,13 & $-1,198$ \\
\hline $\begin{array}{l}\text { Ürünlerimizin dağıtımında nakliye } \\
\text { güçlükleri yaşamaktayız. }\end{array}$ & 117 & 2,4615 & 1,26313 & 0,584 & $-0,739$ \\
\hline $\begin{array}{l}\text { Ürünlerin kalite standartlarının } \\
\text { düşük olması ihracatımızı olumsuz } \\
\text { etkilemektedir. }\end{array}$ & 118 & 2,3983 & 1,21346 & 0,709 & $-0,357$ \\
\hline $\begin{array}{l}\text { İhraç bedeli tahsilatının zor } \\
\text { olmasından dolayı ihracatımızda } \\
\text { zorluk çekiyoruz. }\end{array}$ & 118 & 2,3983 & 1,2618 & 0,48 & $-0,935$ \\
\hline $\begin{array}{l}\text { Kapasite yetersizliğinden dolayı } \\
\text { ihracatta güçlük çekiyoruz. }\end{array}$ & 118 & 2,2542 & 1,22779 & 0,825 & $-0,241$ \\
\hline $\begin{array}{l}\text { Ürünlerin ambalajlanmasında ve } \\
\text { etiketlenmesinde zorluk çekiyoruz. }\end{array}$ & 119 & 2,0924 & 1,12741 & 1,151 & 0,833 \\
\hline
\end{tabular}

Tablo 6'da ise, Antalya ilinde faaliyet gösteren ve dış ticaret yapan KOBİ'lerin ihracat sorunlarına ilişkin ifadelerinin üçün altında ortalamaya sahip olanları verilmiştir. Bu firmaların dış ticaret süreçlerinde en az yaşadıkları sorunlar: ambalajlama sorunu, kapasite yetersizliği sorunu, tahsilat sorunu, kalite standartları sorunu, nakliye sorunu ve pazar araştırması sorunu olduğu tespit edilmiştir (Tablo 6). 
Tablo 7: Varyans Test Sonuçları (Döviz Kuru Hareketlilik)

\begin{tabular}{lcccc}
\hline & $\begin{array}{c}\text { Levene } \\
\text { İstatistiği }\end{array}$ & $\begin{array}{c}\text { Levene İstatistiği } \\
\text { Olasılık Değeri }\end{array}$ & $\begin{array}{c}\text { F } \\
\text { değeri }\end{array}$ & $\begin{array}{c}\text { Olasılık } \\
\text { Değeri }\end{array}$ \\
\hline $\begin{array}{l}\text { Personel Sayıs1 -Döviz } \\
\text { Kurundaki hareketlilik }\end{array}$ & 1705 &, 170 & 2701 &, 049 \\
\hline $\begin{array}{l}\text { Işletmenin faaliyet alanı-Döviz } \\
\text { kurundaki hareketlilik }\end{array}$ & 1326 &, 232 & 3191 &, 002 \\
\hline $\begin{array}{l}\text { Pazarlama Faaliyet yürütücüsü- } \\
\text { Döviz Kurundaki hareketlilik }\end{array}$ &, 635 &, 594 & 3178 &, 027 \\
\hline
\end{tabular}

Antalya ilinde faaliyet gösteren KOBİ'lerin ihracat süreçlerinde yaşadıkları en önemli sorunun döviz kurundaki hareketlilik olduğu yukarıda belirtilmiştir. Çalışmanın bu kısmında bu sorunun aynı firmalara ait demografik özelliklerle olan istatistiksel farklılıklar analiz edilmeye çalışılmıştır. Analizler için varyans testi kullanılmıştır (Tablo 7). Varyans testi ikiden fazla grup olan ve diğer değişkenlerle istatistiksel anlamlılık farklılığın tespiti için kullanılır. Bu analizin iki varsayımı vardır.

Birincisi ilgili değişkenlerin verileri normal dağılmalıdır. Normal dağılım varlığının tespiti için basıklık ve çarpıklık değerli kullanılmış olup ilgili değerler Tablo 5 ve Tablo 6' da verilmiştir. Değerlerin +2 ile -2 aralığında değişiyor olması veri setinin normal dağılım (Morgan vd., 2004:59) sorununun olmadığını gösterir. Diğer varsayımı ise, model varyanslarının homojen dağılmasıdır (Büyüköztürk, 2007:47). Varyansların homojenliğinin tespiti için Levene istatistiği kullanılmış olup her değişken için olasılık değerleri Tablo 7'de verilmiştir. Tablo 7 incelendiğinde her üç levene istatistiği olasılık değeri .005 'den büyük çıkmıştır. Dolayısıyla varyansların homojen dağıldığı söylenebilir (Kalaycı, 2005:219).

Ayrıca sonuçlar incelendiğinde Antalya ilinde döviz kuru hareketliliğin ihracatı olumsuz etkilediği düşüncesini personel sayısı, işletmenin faaliyet alanı ve pazarlama faaliyetlerinin kim tarafından yürütüldüğünden etkilendiği görülmüştür.

Tablo 8: Varyans Test Sonuçları (Ambalajlama Sorunu)

\begin{tabular}{lcccc}
\hline & $\begin{array}{c}\text { Levene } \\
\text { İstatistiği }\end{array}$ & $\begin{array}{c}\text { Levene İstatistiği } \\
\text { Olasılık Değeri }\end{array}$ & F değeri & $\begin{array}{c}\text { Olasılık } \\
\text { Değeri }\end{array}$ \\
\hline $\begin{array}{l}\text { Hukuki Yapı - } \\
\text { Ambalajlama Sorunu }\end{array}$ & 3481 &, 034 & 6747 &, 002 \\
\hline $\begin{array}{l}\text { Pazarlama departman varlığ1- } \\
\text { Ambalaj Sorunu }\end{array}$ & 4866 &, 026 & 6846 &, 010 \\
\hline
\end{tabular}

Tablo 8'de ise, Antalya ilinde faaliyet gösteren KOBİ'lerin dış ticaret süreçlerinde en az etkilenen sorunu olan ambalajlama sorununun bazı demografik özelliklerle farklılık gösterip göstermediği analiz edilmiştir. İki değişken için değişen varyans sorunu olmakla birlikte hukuki yapı ve pazarlama departmanın varlığı ambalajlama sorununu ihracatı olumsuz etkileme düşüncesini etkilemiştir. 
Tablo 9: Lojistik Regresyon Sonuçları (Döviz Kuru Dalgalanmasından Etkilenme)

\begin{tabular}{lccccc}
\hline Bağımsız Değişken & $\begin{array}{c}\text { Omnibus } \\
\text { (model) } \\
\text { Sonuçları }\end{array}$ & $\begin{array}{c}\text { Nagelkerke } \\
\text { R-Kare } \\
\text { Sonuçları }\end{array}$ & $\begin{array}{c}\text { Olasılık } \\
\text { Değeri }\end{array}$ & B & Exp(B) \\
\hline Personel Sayısı & $5326-, 021$ &, 059 &, 025 &,- 483 &, 617 \\
\hline Faaliyet Alanı & $13528-, 000$ &, 145 &, 000 &,- 245 &, 783 \\
\hline $\begin{array}{l}\text { İhracat kredilerinin yetersizliği } \\
\text { beklentisi }\end{array}$ & $8819-, 003$ &, 097 &, 004 &, 421 & 1,524 \\
\hline $\begin{array}{l}\text { Ülke ekonomisindeki } \\
\text { istikrarsızlığın olumsuz etki } \\
\text { beklentisi }\end{array}$ & $9222-, 003$ &, 102 &, 003 &, 434 & 1,543 \\
\hline $\begin{array}{l}\text { Uluslararası reklam maliyetlerinin } \\
\text { yüksekliğinin olumsuz etki } \\
\text { beklentisi }\end{array}$ & $14566-, 000$ &, 156 &, 000 &, 586 & 1,797 \\
\hline $\begin{array}{l}\text { Aracı maliyetlerinin fiyata } \\
\text { olumsuz etkisi }\end{array}$ & $5926-, 015$ &, 066 &, 017 &, 337 & 1,401 \\
\hline \begin{tabular}{l} 
Pazar araştırması sorunu \\
\hline
\end{tabular} & $4024-, 045$ &, 045 &, 048 &, 288 & 1,333 \\
\hline
\end{tabular}

$\mathrm{P}<0,05$

Uygulama bölümünün son kısmında Antalya ilinde faaliyet gösteren ve ihracat yapan 119 KOBİ'nin dış ticaret geliştirmede en önemli sorunu olan döviz kurunda dalgalanmayı etkileyen faktörler lojistik regresyon modeli yardımıyla incelenmiştir. Bu kısımda bağımlı değişken olarak firmanın döviz kuru dalgalanmasından etkilenme oranı ikili kod haline getirilmiştir. Lojistik Regresyon modellerinde bağımsız değişkenin etkisini ölçebilmek için bağımlı değişkenin çok değişkenli olmak yerine ikili değişken olmak zorundadır. Bu sayede bağımsız değişkendeki bir harekette bağımlı değişkenin yönünün hesaplamak mümkündür. Döviz kuru dalgalanmasındaki etkilenmeyi lojistik regresyon modeliyle analiz edebilmek için beşli likert anket ile toplanan verilerde ortalama değer üç olduğu için bağımlı değişken aşağıdaki gibi kodlanmıştır.

Döviz kuru dalgalanmasından etkilenme $>3=1$

\section{- Bağımlı Değişkenin Kodlanması}

Döviz kuru dalgalanmasından etkilenme $<3=0$

Tablo 9 incelendiğinde ihracat kredilerinin yetersizliği beklentisi, ülke ekonomisindeki istikrarsızlığın olumsuz etki beklentisi uluslararası reklam maliyetlerinin yüksekliğinin olumsuz etki beklentisi, aracı maliyetlerinin fiyata olumsuz etkisi, pazar araştırması sorunu arttıkça firmaların döviz kuru dalgalanmasından etkilenmesi de artmaktadır. Fakat personel sayısındaki artış döviz kuru dalgalanmasından olumsuz etkilenmeyi azaltmaktadır.

Ayrıca değişkenin Omnibus sonuçları modelin bir bütün olarak anlamlı olduğunu, olasılık değeri ise katsayıların .005 anlamlılık seviyesinde anlamlı olduğunu göstermektedir (Kalaycı, 2005: 284). Döviz kuru dalgalanmasının olumsuzluğunu en çok etkileyen uluslararası 
reklam maliyetlerinin yüksekliği beklentisi olmuştur. İlgili değişkenin Exp (B) katsayısının 1.79 olması KOBİ'lerin reklam maliyetlerinin yüksekliği nedeniyle uluslararası pazarlama güçlüğü çekmesi arttıkça döviz kuru dalgalanmasından 1.79 kat olumsuz etkilendiklerini göstermektedir (Kalaycı, 2005:284). Exp (B) katsayılarının yorumlanmasında \% 95 güven aralığı kullanılmış olup bu durum tablonun altında belirtilmiştir $(\mathrm{p}<0,05)$.

\section{Sonuç}

Gelişmekte olan ekonomilerin geleceğini inşa etmede uluslararası ticaret, stratejik bir role sahiptir. Kalkınma süreçlerinde bu ekonomilerin iktisadi kriz geçmişleri incelendiğinde cari açık kaynaklı olan ve yerli paranın değer kaybetmesi ile sonuçlanan çok fazla ekonomik kriz söz konusudur. İktisadi karar vericiler ister makro boyutta ister bölgesel boyutta politika üretirken, ülkenin cari dengesinin lehine politikalar üretmek zorundadır. Aksi takdirde uygulanan iktisat politikalarında beklenen sonuçlarda sapmalar meydana gelebilmektedir.

$\mathrm{Bu}$ çalışmada Antalya ilinde faaliyet gösteren 119 KOBİ'ye uygulanan bir anket yardımıyla Antalya ilinin dış ticaret gelişim sürecinde yaşadığı sorunlar tespit edilmeye çalışılmıştır. Sonuçlar göstermektedir ki; Antalya ilinin dış ticaret sürecinde yaşadıkları en önemli sorunlar döviz kurundaki hareketlilik, ülke ekonomisindeki istikrarsılık, devlet desteğinin yetersiz olması ve dış ticaret mevzuatında yaşanan sürekli değişiklikler şeklinde belirlenmiştir. Ayrıca, Antalya ilinin dış ticaret sürecinde en az yaşadığı sorunlar ise sırasıyla ambalajlama, kapasite yetersizliği, tahsilat, kalite standartları, nakliye ve pazar araştırması sorunu olduğu tespit edilmiştir.

Ayrıca, en önemli sorun olan döviz kurundaki hareketlilik anket yardımıyla elde edilen personel sayısından, işletmenin faaliyet alanından ve pazarlama faaliyet yürütücüsünün değişmesinden etkilenmiştir. Çalışmada logit modeli yardımıyla KOBİ'lerin döviz kuru dalgalanmasından etkilenme nedenleri de incelenmiş olup, uluslararası reklam maliyetlerinin olumsuz etkisi ve ülke ekonomisinde istikrarsızlık arttıkça firmaların döviz kuru dalgalanmasından daha çok etkilendiği saptanmıştır.

\section{Kaynakça}

Ahmed, Z. U., Craig, J. C., Baalbaki, I., \& Hadadian, T. V. (2004). Export barriers and firm internationalisation: A study of Lebanese entrepreneurs. Journal of Management and World Business Research, 1(1), 11-22.

Albaum, G. (1983). Effectiveness of government export assistance for US. International Marketing Review, 1(1), 68-75.

Altıntaş, M. H., Tokol, T., \& Harcar, T. (2007). The effects of export barriers on perceived export performance: An empirical research on SMEs in Turkey. EuroMed Journal of Business, 2(1), 36-56.

Bagchi-Sen, S. (1999). The small and medium sized exporters' problems: An empirical analysis of Canadian manufacturers. Regional Studies, 33(3), 231-245.

BAKA. (2014). Batı Akdeniz Dış Ticaret Analizi 2002-2013. Erişim tarihi: 03.06.2017, http:// www.baka.org.tr/uploads/7434546767dis_ticaret_analizi_2002-2013.pdf 
Balantekin, B. E. (2006). İhracatta KOBİ'lere sağlanan devlet destekleri ve KOBİ'lerin ihracatta karşılaştıkları sorunlar ve Kayseri' de bir anket uygulaması. (Yayınlanmamış yüksek lisans tezi). Erciyes Üniversitesi Sosyal Bilimler Enstitüsü, Kayseri.

Bilkey, W., \& Tesar, G. (1977). The export behavior of smaller-sized Wisconsin manufacturing firms. Journal of International Business Studies, 8(1), 93-98.

Bilkey, W. J. (1978). An attempted integration of the literature on the export behavior of firms. Journal of International Business Studies, 9(1), 33-46.

Bodur, M. (1986). A study on the nature and intensity of problems experienced by Turkish exporting firms. Advances in International Marketing, 1, 205-32.

Büyüköztürk, Ş. (2007). Sosyal bilimler için veri analizi el kitabı. 7. Bask1, Ankara: Pegem Yayıncilik.

Çavuşgil, S. T., \& Zou, S. (1994). Marketing strategy-performance relationship: an investigation of the empirical link in export market ventures. The Journal of Marketing, Vol. 58, 1-21.

Çoban, S. (2005). Kayseri mobilya sanayinin dış ticaret yapısı ve sorunlarına yönelik bir araştırma. Selçuk Üniversitesi Karaman İktisadi ve İdari Bilimler Dergisi, 5(2), 73-82.

Delice, G. (2001, Ekim). KOBÍlerin ihracata yönlendirilmesinde finansman destekleri; Türk Eximbank kredileri üzerine bir uygulama. 1. Orta Anadolu Kongresi - KOBİ'lerin Finansman ve Pazarlama Sorunları, Nevşehir, 269-281.

Demirel, M. M., \& Sezgin, S. (2006). KOBİ'lerin dış pazarlara açılma problemleri. İTÜ DERGISİ/d, 5(2), 116-124.

Dichtl, E., Leibold, M., Köglmayr, H. G., \& Mueller, S. (1984). The export-decision of small and medium-sized firms: A review. Management International Review, 24, 49-60.

Dichtl, E., Koeglmayr, H. G., \& Mueller, S. (1990). International orientation as a precondition for export success. Journal of International Business Studies, 21, 23-40.

Erdoğan, Z., \& Develioğlu, K. (2009). Girişimcilik ve KOBİler teori ve uygulama. Zafer Erdoğan (ed.), 2. Baskı, Bursa: Ekin Basım Yayın Dağıtım.

Ergen, A. G. (2011). KOBİ’lerin uluslararası pazarlara açılmasında sektörel dış ticaret şirketleri modeli ve konserve meyve-sebze sektöründe uygulanabilirliğinin araştırılması. (Yayınlanmamış yüksek lisans tezi). Ankara Üniversitesi, Sosyal Bilimler Enstitüsü, Ankara.

Freeman, C. (1991). Networks of innovators: A synthesis of research issues. Research Policy, 20(5), 499-514.

Hook Jr, R. C., \& Czinkota, M. R. (1988). Export activities and prospects of Hawaiian firms. International Marketing Review, 5(4), 51-57.

Iş1k, N., \& Delice, G. (2007). Küreselleşme sürecinde kobi'lerin ihracat sorunları ve e-ticaret. Karamanoğlu Mehmetbey Üniversitesi Sosyal ve Ekonomik Araştırmalar Dergisi, 3 , 75-89.

Kalaycı, Ş. (2005). SPSS uygulamalı çok değişkenli istatistik teknikleri. 1. Baskı Ankara: Asil Yayın Dağıtım.

Karafakioglu, M. (1986). Export activities of Turkish manufacturers. International Marketing Review, 3(4), 34-43. 
Karakaya, F., \& Harcar, T. (1999). Barriers to export for non-exporting firms in developing countries. Academy of Marketing Studies Journal, 3(2), 59-77.

Karamustafa, O., Çetin, M., Karakaya, A., \& Taslak, S. (2001). KOBI’lerin ihracat darlı̆̆ nedenleri üzerine bir araştırma: Samsun ili örne ği. I. Orta Anadolu Kongresi KOBİ'lerin Finansman ve Pazarlama Sorunları, Nevşehir, 269-281.

Katsikeas, C.S., \& Morgan, R.E. (1994). Differences in perceptions of exporting problems based on firm size and export market experience. European Journal of Marketing, $28(5), 17-35$.

Kaymak, O. (2015). Türkiye'deki KOBİ'lerin mevcut durumlarının analizi ve ticari uygulamaları. (Yayınlanmamış yüksek lisans tezi). Dicle Üniversitesi, Sosyal Bilimler Enstitüsü, Diyarbakır.

Keskin, G., Koşan, A. K., \& Ayık, Y. Z. (2009). Bölgesel gelişme aracı olarak KOBİ'ler ve ihracat sorunları (Erzurum'da bir araştırma). Atatürk Üniversitesi Sosyal Bilimler Enstitüsü Dergisi, 13(2), 279-290.

Khattak, J. K., Arslan, M., \& Umair, M. (2011). SMEs' export problems in Pakistan. Journal of Business Management and Economics, 2(5), 192-199.

Köksal, M. H., \& Kettaneh, T. (2011). Export problems experienced by high-and lowperforming manufacturing companies: A comparative study. Asia Pacific Journal of Marketing and Logistics, 23(1), 108-126.

Leonidou L. (1995). Export barriers: non-exporters' perceptions. International Marketing Rev., 12(1), 4-25.

Leonidou L. (2004). An analysis of the barriers hindering small business export development. Journal Small Business Management, 24(3), 279-302

Lyons, D. (1995). Changing business opportunities: The geography of rapidly growing small US private firms, 1982-1992. The Professional Geographer, 47(4), 388-398.

Morgan, R. E. (1997). Export stimuli and export barriers: Evidence from empirical research studies. European Business Review, 97(2), 68-79.

Morgan, R. E., \& Katsikeas, C.S. (1997). Obstacles to export initiation and expansion, Omega, 25(6), 677-690.

Morgan, B. George, A., Nancy. L.L., Gloeckener, G.W., \& Karen, C. B. (2004). SPSS for introductor statistics: Use and interpretation. Second Edition, London: Lawrance Erlbaum Associates.

Özgener, Ş. (2003). Büyüme sürecindeki KOBİ'lerin yönetim ve organizasyon sorunları: Nevşehir un sanayii örneği. Erciyes Üniversitesi İktisadi ve İdari Bilimler Fakültesi Dergisi, 20, 137-161.

Pinho, J. C., \& Martins, L. (2010). Exporting barriers: Insights from Portuguese small-and medium-sized exporters and non-exporters. Journal of International Entrepreneurship, $8(3), 254-272$.

Rocha, A. D., Freitas, Y. A., \& Silva, J. F. D. (2008). Do perceived export barriers change over time? A longitudinal study of Brazilian exporters of manufactured goods. Latin American Business Review, 9(1), 102-128. 
Rothwell, R. (1991). External networking and innovation in small and medium-sized manufacturing firms in Europe. Technovation, 11(2), 93-112.

Shaw, V., \& Darroch, J. (2004). Barriers to internationalisation: a study of entrepreneurial new ventures in New Zealand. Journal of International Entrepreneurship, 2(4), 327-343.

Sönmez, A., \& Arslan, A. R. (2007). İhracat yapma şekline göre karşılaşılan sorunlar; Mobilya endüstrisi örneği. Politeknik Dergisi, 10(4), 403-409.

Şahin, Ş. (2016). Kümelenmenin KOBİ'lerin ihracat performansına etkisi: Kuyumcukent örneği. (Yayınlanmamış yüksek lisans tezi). İstanbul Ticaret Üniversitesi Dış Ticaret Enstitüsü, İstanbul.

Tesfom, G., \& Lutz, C. (2006). A classification of export marketing problems of small and medium sized manufacturing firms in developing countries. International Journal of Emerging Markets, 1(3), 262-281.

TOBB. (2017). Türkiye'de KOBİ tanımı. Erişim Tarihi: 10.07.2017, https://www .tobb.org.tr/ KobiArastirma/Sayfalar/KOBITanimi.php

TÜİK. (2016). Küçük ve Orta Büyüklükteki Girişim İstatistikleri. Erişim Tarihi: 14.07.2017, http://www.tuik.gov.tr/PreHaberBultenleri.do?id=21540

TÜIKK. (2017). Dış Ticaret İstatistikleri. Erişim Tarihi: 14.07.2017 https://biruni.tuik.gov.tr/ disticaretapp/menu.zul

Zou, S., \& Stan, S. (1998). The determinants of export performance: A review of the empirical literature between 1987 and 1997. International Marketing Review, 15(5), 333-356. 